\title{
戦前期教科書の電子化·保存とその応用 \\ Digitalization, Preservation and Application of Pre-war Textbook
}

\author{
江草由佳 $* 1$ \\ Yuka EGUSA
}

*1 国立教育政策研究所教育研究情報センター

Educational Resources Research Center, National Institute for Educational Policy Research ₹ 153-8681 東京都目黑区下目黑 6-5-22

E-mail: yuka@nier.go.jp

日本の教科書のうち，特に現行の検定教科書以前に使用された戦前教科書の電子化と応用 の現状を述べ, ケーススタディとして国立教育政策研究所教育研究情報センター教育図書館 が所蔵する戦前教科書の電子化, 保存と关の応用について述べる。

This paper reports digitalization and utilization of Japanese old textbook which was used before current Japanese textbook, "Sengo-Kentei-Kyokasho", has been used. As a case study, Library of Education's services for the old textbook collection are reported.

キーワード： 戦前教科書，電子化，提供，

Pre-war textbook, digitalization, service

\section{1 はじめに}

本稿では, 現行の検定教科書以前の教科 書 (以降「戦前教科書 $\lrcorner^{* 1}$ と呼ゔ)の電子化や 弚の応用について述べる.ケーススタディ として, 国立教育政策研究所教育研究情報 センター教育図書館 (以降「教育図書館」と 呼ゔ) が戦前教科書の電子化等に対して実践 していることについて述べる . 教育図書館 は , 江戶後期から現行の検定教科書までの 長い期間にわたる日本の教科書を網羅的に 所蔵している。

\section{1 教科書とは}

現行の教科書 (戦後の検定教科書) は正式 には，「教科用図書検定規則 (平成元年 4 月 4 日文部省令第 20 号)」にある「(教科用図 書) 第 2 条この省令において『教科用図書』 とは、小学校、中学校、中等教育学校、高等 学校並びに盲学校、壟学校及び養護学校の 小学部、中学部及び高等部の児童又は生徒

*1 厳密に「戦前」に限られず、戦後 1947 年 4 月に 現行の検定教科書制度が開始するまでに使用さ れた教科書を指す。
が用いるため、教科用として編修された図 書」と定義され，この「教科用図書」のこと を一般的には「教科書」と呼んでいる．この ことから，教科書とは狭義には，明治初期以 降の近代教育制度の元での公教育の場で使 用されたものに限った教科用の図書 [1] と いえる．教科書に関連したものとして，教 科書に対応した指導書や副教材などもある．

「日本の教科書制度は, 明治初年の自由発 行・自由採択制から開申 (届出) 制度, 認定 制となり，やがて 1886(明治 19) 年に検定 制，光して 1904(明治 37) 年に『国定教科書 制度』の実施となる．以後敗戦後の1947(昭 和 22) 年 3 月まで国定教科書が使用され」 [2], 光の後現行の検定教科書が使用される ようになる．本稿では，「教科書」を現行の 教科書の定義より広くとり，広義としての 教科書を対象とし，江戶時代の寺子屋で使 用された往来物や各種学校等で使用された ものなども含めることとする．また，特に， 1947(昭和 22) 年 3 月までの古い教科書を主 な対象とするため, 本稿で対象とする古い 教科書を総称して「戦前教科書」と呼ふジこ 
ととし, 戦前を付けず「教科書」と呼んだ場 合は, 現行の検定教科書を含めたものを指 すこととする .

\section{2 戦前教科書の利用}

教科書の利用というと，いわゆる授業で 用いる教科書として使用するという場合と， 研究等の資料として, またはなんらかの情 報要求の解決のための資料として使用する 場合とが考えられるが, 戦前教科書の利用 といった場合は, 後者の場合がほとんどで あろう.このような戦前教科書の利用ニー ズには樣々なものがある .

まずは，教科書を使ったもしくは教科書 を対象とした研究が挙げられる. 教科書関 係文献目録 [3] の分類では, 総記, 教科書 論，往来物，近代日本教科書史，教科書行財 政, 教科書・教材, 各教科の教科書, 外国教 科書, 特定主題研究, 教科書上の人物研究 が大分類として挙げられており, 樣々な研 究がある .

第一には，社会に与える教科書の影響や， 教科書の実態をあきらかにするといった教 科書谷のものについての研究 [2][4] がある. 例えば, 明治期の検定教科書を調べる際に は，検定を経て，検定で指摘された箇所を 修正し，実際に教育現場で使用された検定 济みの教科書を研究の材料として使用する 重要性について指摘し, 教育図書館や東書 文庫に所蔵されている明治期検定教科書は 基本的に国が検定の際に用いた検定前の教 科書が多く含まれていることを調査し, 検 定前のものである確率が高い初版を底本と することの危険性を指摘しているもの [5] などがある . 教科書を使った研究の多くは， 各教科の研究の一環として, 教科書を題材 にするというものである . 例えば，歴史教 科の研究として, 教科書に使われている「歴 史画」に着目して，歴史画が歴史教科書に どのように採用されていったか，どのよう に教育界に影響を与えていったかといった 研究 [6] などである. 产の他にも，特定の教 科書に着目した研究 [7], 教科書に登場する 人物に着目した研究 [8] など樣々な研究が ある 。
教科書は誰もが児童・生徒として利用し た身近な書籍である，同年代の者が共通し て利用した書籍であるという特性により， 以前使用した教科書をもう一度みてみたい ということがよくある．例えば，教育図書 館によく寄せられるレファレンスを例に挙 げると，「同密会で昔の教科書に載っていた 唱歌を歌いたいので，唱歌の伴奏があるも のを知りたい」,「自身が使用した教科書が 見たい」などがある．また，終戦前後の特 殊な教科書 (墨塗り教科書，折りたたんだだ けの教科書) を見たいといった利用も見ら れる。

\section{3 戦前教科書の所蔵機関}

戦前教科書を大規模に所蔵するのは, 教 育図書館に加え, 東書文庫, 東京学芸大学 附属図書館，国立国会図書館，奈良女子大 学附属図書館, 重要文化財旧開智学校管理 事務局, 文部科学省初等中等教育局初等課, 海後宋臣氏，吉野文庫など 8 機関 1 個人あ る [9][10] .

教育図書館の戦前教科書コレクションは， 国立国会図書館上野支部の書庫が収蔵しき れなくなったことと，教育図書館による「教 育文献総合目録 第 3 集 教科書総合目録」の 編集企画があったことにより，昭和 25 年 3 月に 52,000 冊寄贈を受けたものが基礎と なっており光の後, 学芸大学, 科学博物館, 気象台等から寄贈されたものもある [11] . 国立国会図書館上野支部から寄贈されたこ の 52,000 冊は , もともとは各教科書出版者 が出版条令や出版法により内務省に版権登 録もしくは検閲用として提出したものが事 後, 国立国会図書館上野支部に納付され，保 管されていたものである [12] .

東書文庫は, 昭和 13 年に文部省より明治 時代を中心とした検定教科書 (小学校, 中学 校, 高等女学校, 師範学校用) 31,800 冊の寄 贈や個人収集家からの寄贈, 図書館か購入し たものなど合せて昭和 15 年には約 55,000 冊となったコレクションが基礎となってい る [13] .

国立国会図書館が所蔵されているもの中 には, 昭和 25 年の教育図書館への寄贈後に 
また，未整理図書を整理して国立国会図書 館所蔵明治期刊行図書目録 [14] を刊行する 際に，発見されたものなどがある [11] .

このような゙状況から，1 つの教科書の上巻 が教育図書館に, 中巻が東書文庫に,下巻 が国立国会図書館に所蔵されているという こともしばしば見うけられる [11] .

ここまでに挙げた所蔵機関は，大規模に 所蔵する機関等であるが, 他の大学図書館 や公共図書館, 各地方の教育センターや教 科書センターでも特定の個人や地域に特定 するなど小規模なコレクションを所蔵して いる機関は多くある .

また, 戦前教科書には, 復刻版として出 版されているものも多くあり，復刻版であ れば，多くの図書館が所蔵している，例え ば福岡県立図書館では 19 種類の復刻版の教 科書を所蔵している [15] . 復刻版には, 教 科書を撮影したりなどして , 教科書の見た 目のままかなり現物に近い形で再現したも のと，教科書中の文字を書き起して活字と して印刷したものとがある. 後者の代表的 なものには，「日本教科書大系近代編」 [16] があり，多くの図書館で所蔵している。「日 本教科書大系近代編」は, 明治期以降から 昭和 22 年までの小学校の教科書を広く収録 したものであり，特に国定期の教科書は全 てが収録されている．もし，教科書の内容 が見たいだけであれば，「日本教科書大系近 代編」に収録されている教科書で十分な場 合も多いだろう.

\section{2 戦前教科書の電子化と公開}

教科書の電子化といった場合, 一次情報 の電子化と二次情報の電子化と大きく $2 つ$ が考えられる.一次情報の電子化とは, 教 科書光のものを撮影するなどして画像化し て, PDF 等のディジタルフォーマットに変 換することである．また，教科書に書かれ ている文字情報を OCR 技術を利用するな どして，書き起こして，テキスト化すること である . 二次情報の電子化とは, 教科書の 二次情報，つまり書誌情報（書名，著者名， 科目名) や, 内容索引 (唱歌の歌い出し, 国
語の作品名，登場人物の人名など）を電子化 することである. 教科書の電子化と公開は 一次資料，二次資料ともに关れほど進んで いないのか現状である .

一次資料の電子化が進んでいない理由の 第一に挙げられるのは, 著作権処理コスト の問題がある . 著作権があるもの，もしく はあるかどうか不明なものに関しては, 著 作権があるかないかの確認作業をしたり， 著作権がある教科書については, 許諾を得 なければ，電子化 (複製)，公開をすること ができないからである．また，教科書は，1 つの教科書の中に多くの作品や図，絵，写 真を使った複合的な著作物であるため，教 科書の編著者以外にも個々の作品の著作権 者にも許諾を得る必要があり，一般の書籍 よりも 1 冊に対する著作権者の数が多いと いう状況もある。

教科書を所蔵するのは図書館だけではな いが, 二次資料の作成は図書館の得意とす るところであり，冊子体の総合目録や内容 索引の多くは図書館が主体となって作成し ている.しかし，これらの教科書の二次資 料もまた，一般の書籍ほどには電子化が進 んでいない，図書館で教科書の二次資料の 電子化が進んでいない理由には，一般の書 籍と同樣の書誌データだけでは，多くの検 索要求を満足することができず，図書館に おける既存の蔵書検索システムに組みこむ ことが難しいことが挙げられる.教科書の 多くの検索要求を満たすためには, 学校種 別 (例：小学校), 学年, 科目 (例：国語) な ど，一般の書籍にはない教科書特有の検索 項目が必要になる.例えば, 多くの大学図 書館が参加している総合目録 NACSIS-CAT では，教科書特有の書誌情報を扱うための コーディングマニュアル [17][18] が整備さ れたのは 2005 年 3 月と最近のことである . また，このマニュアルは原則として対象が 現行の検定教科書に限られているだけでな く，学年など一部の検索項目も対応してい ないという状況である . 


\section{1 一次資料の電子化例}

一次情報の電子化を行い，現在公開して いる例としては, 広島大学図書館所蔵教科 書コレクション*2がある.これは, 広島大学 の中央図書館に所蔵されている教科書の中 から、江戶時代の寺子屋で使用された「往来 物」から昭和 25 年までの教科書を画像化し たものであり，約 5,600 冊収録されている [19] . 教科書の時代区分として ,大きくわけ

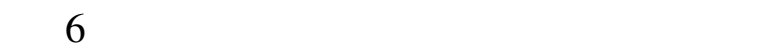
公開については，表 1 に示すとおり，古い ものは全ページが公開されており，最近の ものほど表紙や目次，奥付など一部のみの ページが公開となっている．例えば，検定 期は 526 件の教科書が登録されており, 光 のうち全ページの閲覧ができるのは 284 件 で残りの 242 件は一部のページのみが閲覧 可能であることを示している .

表 1 広島大学図書館所蔵教科書 コレクションの全文公開状況*

\begin{tabular}{|c|c|c|c|}
\hline \multicolumn{2}{|c|}{ 時代区分 } & $\begin{array}{l}\text { 登録 } \\
\text { 件数 }\end{array}$ & $\begin{array}{c}\text { 全頁 } \\
\text { 電子化 }\end{array}$ \\
\hline 学制以前 & ～明治 4 年 & 521 & 521 \\
\hline 検定以前 & ～明治 18 年 & 799 & 797 \\
\hline 検定期 & ～明治 35 年 & 526 & 284 \\
\hline 国定期 & ～昭和 20 年 & 3,200 & 9 \\
\hline 文部省著作期 & ～昭和 23 年 & 196 & 0 \\
\hline 現行 & 昭和 24 年〜 & 365 & 0 \\
\hline
\end{tabular}

*2007 年 10 月現在, 筆者による計数

他には東京学芸大学付属図書館望月文 庫往来物目録・画像データベース ${ }^{* 3}$ などが ある

\section{2 二次資料の電子化例}

基本となる二次資料として冊子体目録が あり,書名, 著者名, 発行年, 学校種別, 教科 書制度 (国定，検定など)，などの書誌データ と所蔵機関がわかる. 戦前教科書の冊子体 目録には, 戦前教科書を大規模に所蔵する 8 機関 1 個人を対象とし，書名ごとにまと

\footnotetext{
*2 http://cross.lib.hiroshima-u.ac. jp/

*3 http: / / library.u-gakugei.ac.jp/ lbhome/mochi/mochi.html
}

めた小学校の戦前教科書の総合目録 [9]や， 教育図書館，東書文庫，国立国会図書館の 3 館が所蔵する中学校の戦前教科書の総合目 録 [20], 東書文庫の所蔵する教科書の一冊 づつについて収録した冊子体目録 [21] など がある . 総合目録 [9][20] については電子化 されていない．東書文庫の冊子体目録 [21] に収録されている教科書の一部については， 東書文庫の蔵書検索*4で検索が可能である． 他には, 明治以降外国語教科書データベー ス*5などがある .

教科書の場合, 教科書炎のものの書名や 著者名での検索要求よりは, 教科書中の作 品の作品名 (国語であれば文学作品, 音楽 であれば曲など），著者名，内容，または唱 歌の歌い出しなどの検索要求も多くある. このようなニーズに対応するために，唱歌 の歌い出し索引や国語の内容索引, 目次索 引などがある．先に挙げた東書文庫の蔵書 検索では，目次を検索することも可能であ る. 戦前の教科書ではないが, 戦後の検定 教科書を対象としたデータベースに, 神奈 川県立総合教育センターが提供しているも のがある .これは, 国語の作品を対象とし たデータベーズと，音楽を対象としたデー タベース ${ }^{* 7}$ がある .

\section{3 教育図書館の戦前教科書の電子 化と応用}

この節では，戦前教科書の電子化と炎の 応用のケーススタディとして，教育図書館 での実践について述べる．

教育図書館について紹介し，教育図書館 の戦前教科書コレクションについて簡単に 述べる .

\footnotetext{
*4 http://bnkweb.tosho-bunko.jp/

*5 http://www. wakayama-u.ac.jp/ rerikawa/index.html

*6 http: / / kjd.edu-ctr.pref. kanagawa.jp/daizai/

*7 http://kjd.edu-ctr.pref. kanagawa.jp/daizai_music/
} 


\section{1 教育図書館の概要}

教育図書館は，教育に関する図書，資料， 教材，教具等を収集・整理し，教育に関す る調査・研究の支援を目的とした専門図書 館である [22]. 利用者は教育研究について 調査・研究する人として当該研究所の所員, 研究者, 教員, 学生, 一般などを対象として おり，所員でなくとも来館利用が可能であ り, また紹介状等も必要ない. 最新の教科 書など一部の所蔵資料は開架式で利用でき るが，多くの資料は閉架式であり，また所 員以外には基本的に貸出は許可していない . 他機関との関係では, NACSIS-CAT に参加 しており, 文献複写サービスや電話でのレ ファレンスなどにも対応している．蔵書に は, 和洋教育関係の図書, 杂倠志のほか, 教科 書. 大学紀要 -地方教育資料・戦後教育資料 などがあり, 平成 17 年度の蔵書数は, 和図 書が 143,146 冊，洋図書が 40,702 冊，教科 書が 98,705 冊, 㫕の他が 199,706 冊で, 合 計 482,259 冊である.

3.2 教育図書館の戦前教科書コレクション 教育図書館が所蔵する戦前教科書は, 第 2 次世界大戦後に現行の検定教科書が使用 されるまでに使われた教科書のコレクショ ンであり，以下があり，約 52,000 冊所蔵し ている。

- 江戶時代の寺子屋で使われた往来物

- 明治初年・検定教科書 (明治 5 年から明 治 36 年)

- 国定教科書 (明治 37 年から昭和 20 年)

- 旧制中学校・高等女学校, 実業高校・師 範学校等教科書

- 暫定教科書・文部省著作教科書

- 植民地教科書

先に 1.3 節で述べたように このコレクショ ンの大部分は昭和 25 年 3 月に国立国会図 書館から寄贈を受けたものである .

3.3 一次資料の電子化

教育図書館では, 劣化が激しく原本から 複写サービスが不可能なもの，もしくは紛 失に対処するために，1964 年 (昭和 39 年) までに検定された教科書を対象として, 電
子化し PDF を作成している．

表 2 作成した PDF の仕樣

\begin{tabular}{c|c|c} 
& 閲覧用 & 保存用 \\
\hline 色数 & $\begin{array}{c}\text { モノクロ }(2005 \text { 年以前 }) \\
\text { /グレースケール }\end{array}$ \\
\hline 解像度 & \multicolumn{2}{|c}{$400 \mathrm{dpi}$} \\
\hline ファイル樣式 & PDF & TIFF Rev.6.0 \\
\hline $\begin{array}{c}\text { ファイル毎の } \\
\text { ファ録分量 }\end{array}$ & 1 冊 & 1 ページ \\
\hline
\end{tabular}

作成したPDF の仕樣を表 2 に示す. 色 数は作成時期によって異なる.2005 年度 まではモノクロで作成し，現在はグレース ケールで作成している．一部，すでにマイ クロフィルムがあるものについては, マイ クロフィルムから作成している . ないもの については，マイクロフィルム作成と同時 にPDF を作成した . また, PDF ファイル名 から請求記号が自動変換できるようにする ために，作成する PDF のファイル名には，

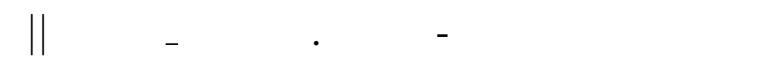
にしている. PDF 作成対象教科書数と PDF 作成済みの件数を表 3 に示す.

表 3 PDF 作成対象教科書と作成 PDF の数

\begin{tabular}{l|r} 
戦前/戦後検定 (色数) & 冊 (PDF) 数 \\
\hline 戦前教科書 (モノクロ) & 36,017 \\
戦前教科書 (グレースケール) & 4,796 \\
戦後検定教科書 (モノクロ) & 5,927 \\
\hline \hline PDF 対象教科書 & 53,417 \\
PDF 作成济み & 40,813 \\
& $(76 \%)$ \\
未作成 [推定]・ & 12,604 \\
戦前教科書 (グレースケール) & $(24 \%)$
\end{tabular}

\section{4 二次資料の電子化}

教育図書館が作成した戦前教科書の二次 資料としては，先に挙げた「戦前教科書の 総合目録」[9][20] と矢れを元にしたカード 目録*8がある．また，教育図書館が作成した

\footnotetext{
*8 江戶時代の往来物についてはカード目録のみ， 冊子体目録には収録されていない .
} 
教科書用の分類表がある .

\subsection{1 冊子体総合目録及びカード 目録}

冊子体総合目録及びカード目録からの電 子化については，江戶時代の往来物約 100 点については後に述べる試作システムに入 力済みである. 谷の他の教科書についても， カード目録をほぼ光のままの形としてタイ ピング入力し ,「請求記号」,「標目」,「内容」 の 3 カラムで入力された CSV データとし て電子化済みである。「標目」は小学校の戦 前教科書は書名標目となっており, 光の他 の学校種別ものは著者名となっている.

\section{4 .2 教科書用の分類表}

教科書を整理し，利用する上で分類表の 作成は欠かせない，全国国立教育系大学附 属図書館協議会では, 加盟教育系大学図書 館の相互利用を目的として，狭義の教科書に 対する標準的な教科書の分類法を策定して いる [1]．教育図書館では，往来物や戦後の 各種学校も含めた広義の教科書を対象とし た教科書の分類法を教育図書館開館後の少 くとも 10 年以内に作成しており [23], 光れ 以降使用しつづけている.この教育図書館 作成の教科書用の分類表については, XML 形式で電子化济みである.

\section{5 電子化資料の提供の理想}

まず，教科書の電子化提供の理想形につ いて述べる.筆者の考える理想形は, 教育 図書館の来館者だけでなく世界中からアク セスし利用可能であること，「書名」「著者 名」「検定の状態」「検定年」「使用年」「学校 種別」「時代区分」「科目」「収録作品名」「収 録作品の著者名」「目次」「登場人物」「件名」 等で検索やブラウジングが可能になること である .

教育図書館では，これらのいくつかの項 目に対して，整理しまとめた冊子体目録が 存在するものの, 全てを満たしているわけ ではない，また, 後に詳しく述べるが, 樣々 な問題・制約等により，これらの理想形に一 足飛びに実現できるわけではないため, 現 状ですぐにサービス化でき光うなものとし て, 検索システムの試験運用, 文献複写用 Web ページ , 請求記号による教科書閲覧シ
ステムの試作の 3 つの提供形態を模索して いる段階である .

3.6 電子化資料の利用:検索システム

著作権の問題が発生しない往来物につい て, 現在，書誌データと本文 PDF を登録済 みの試験運用中の検索システムがある . 図 1,2,3 は炎の画面例である .

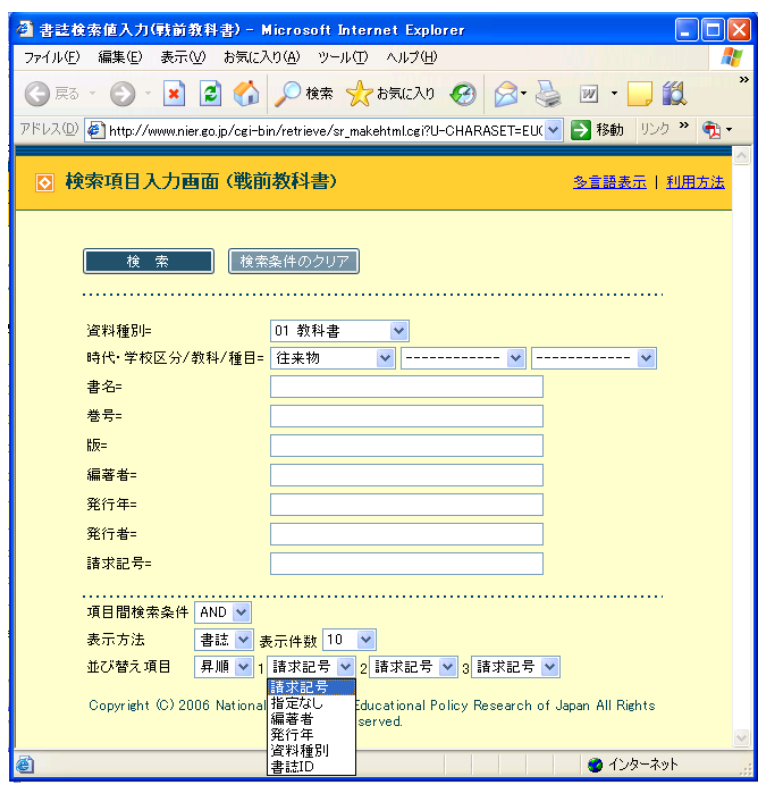

図 1 検索画面

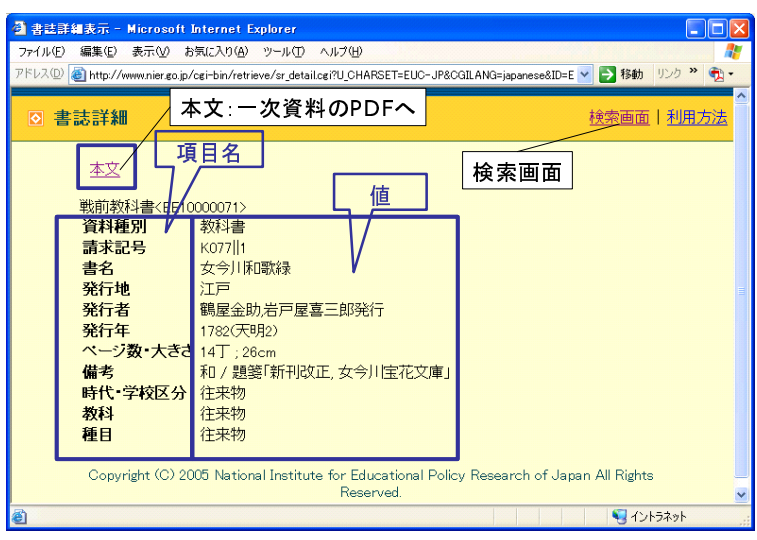

図 2 検索結果詳細画面

この検索システムに入力した書誌項目名 としては, 書誌 ID, 目録規則, 書名, 別夕 イトル, 巻, 版, 編著者, 発行地, 発行者, 書誌 ID，目録規則，書名，別タイトル，巻， 版, 編著者, 発行地, 発行者がある.詳細に ついては [24]を参照していただきたい． 


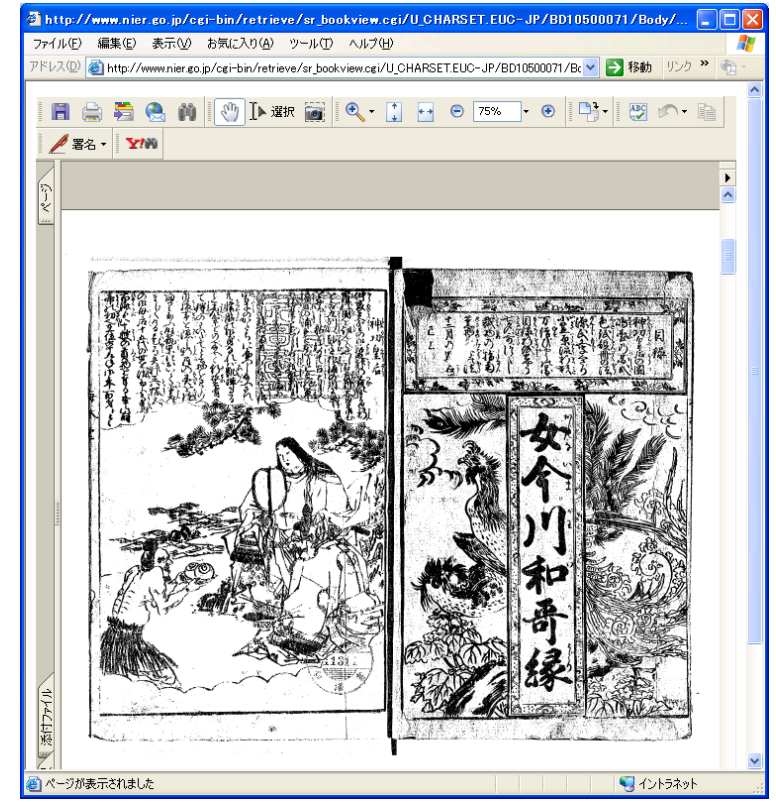

図 3 本文 PDF の表示画面

\section{7 電子化資料の利用:文献複写用 Web ページ}

利用者からの複写依頼を受けて, 図書館 員だけが使用可能なWeb ページを作成して いる.図 4，5 は光の画面例である.

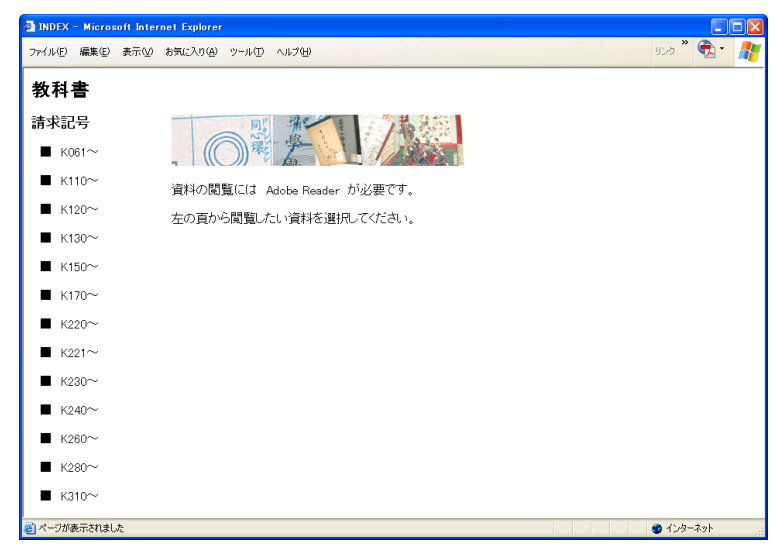

図 4 文献複写用 Web ページの初期画面

請求記号と，ページ数が記載されており， PDF 表示のリンクをクリックすると, 該当 する教科書が表示される仕組みである .

3.8 電子化資料の利用:請求記号による教 科書閲覧システム

先に述べた文献複写用ページをさらに発 展したものとなるように，試作したものであ

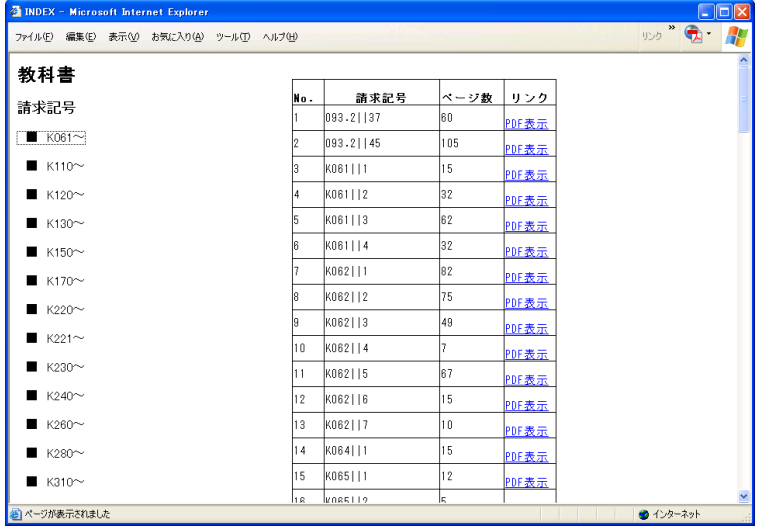

図 5 文献複写用 Web ページの

K061 を選択したところ

る. 請求記号での前方一致検索と，分類 (請 求記号の || 以前は教科書の分類を表わす) によるブラウジングの機能がある . 図 6 は 初期画面であり，請求記号の前方一致検索の 入力ボックスと, 請求記号の冒頭の分類から 辿れるようにリンクのはられた分類体系が 表示されているところである. 図 7 は, 初 期画面から分類を $\ulcorner K 120 」,\ulcorner K 120.1 」$ と辿っ ていったところである．辿っていった軌跡 がわかるように,上部にパンクズリストとし て , 分類構造がわかるように,「Top(リンク) $>>\mathrm{K} 120$ 明治検定教科書 M20 36(18871903)(リンク) $>>$ K120.1」としている . ま た，辿った分類での前方一致検索がすぐ にできるように，検索クエリボックスに $\ulcorner\mathrm{K} 120.1\lrcorner$ が自動的に入力されているところ を表したところである. 請求記号と光れに 対応する書誌データが表示されており, 請 求記号のリンクをクリックすると，乥の請 求記号が示す詳細画面へと移行する.図 8 は，請求記号「K120.1 $\mid 1 」$ 」を辿ったところ である．書誌データと，本文へのリンクが 示される.図 9 は, 検索クエリボックスに 入力された $\ulcorner\mathrm{K} 120.1 \| 1 」$ を前方一致検索し た結果を表している.請求記号のリンクは 該当書誌データへのリンクを表し，URLの リンクは本文を表わしている . 


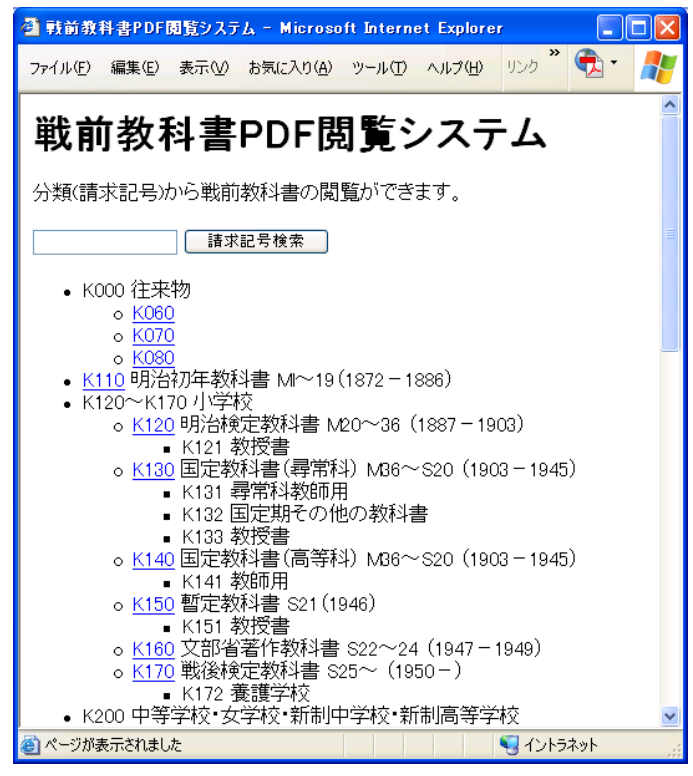

図 6 請求記号による教科書閲覧 システム : 初期画面

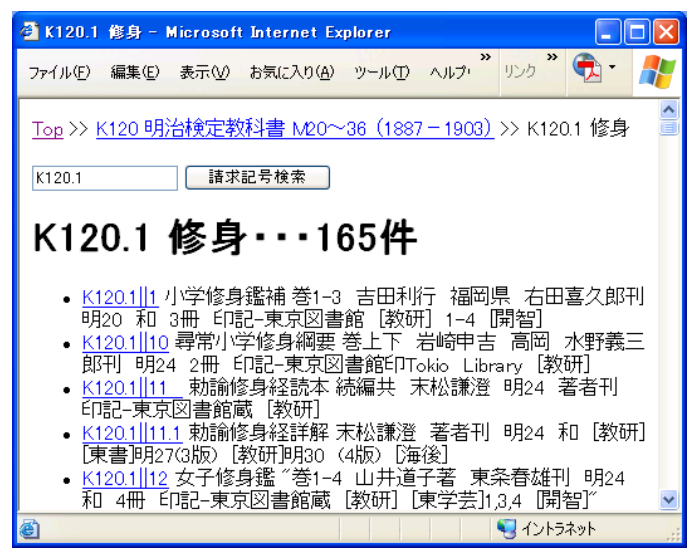

図 7 請求記号による教科書閲覧 システム : 分類 K120.1 を辿った ところ

\section{9 教育図書館における電子化資料利用の 検討課題}

前節までに述べた現状の試作ツールの本 格的な運用に向けては, 大きく分けて $2 つ$ の課題がある.1つは著作権処理等の法的 な処理である .もう 1 つは電子的提供に耐 えられる書誌データのブラッシュアップの 必要性である。

\subsection{1 著作権処理等の法的な処理}

教育図書館では，「著作権法第 31 条二号 『図書館資料の保存のため必要がある場合』

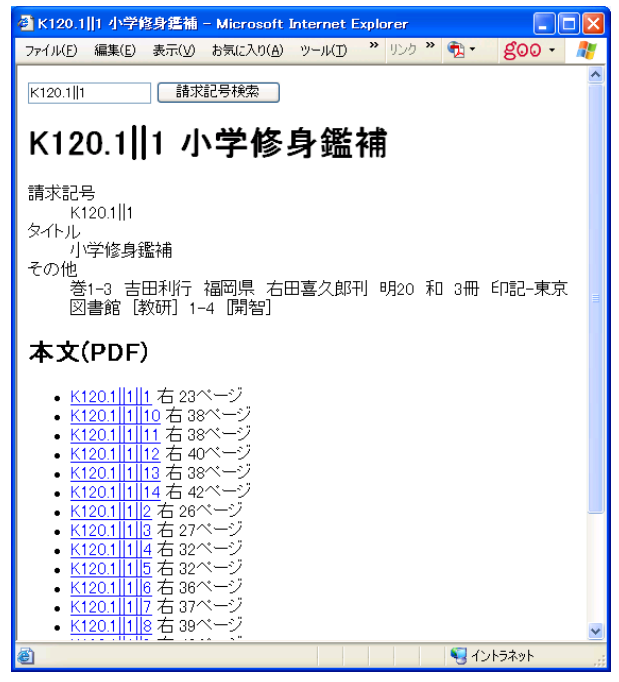

図 8 請求記号による教科書閲覧 システム : 請求記号「K120.1||1」 の表示

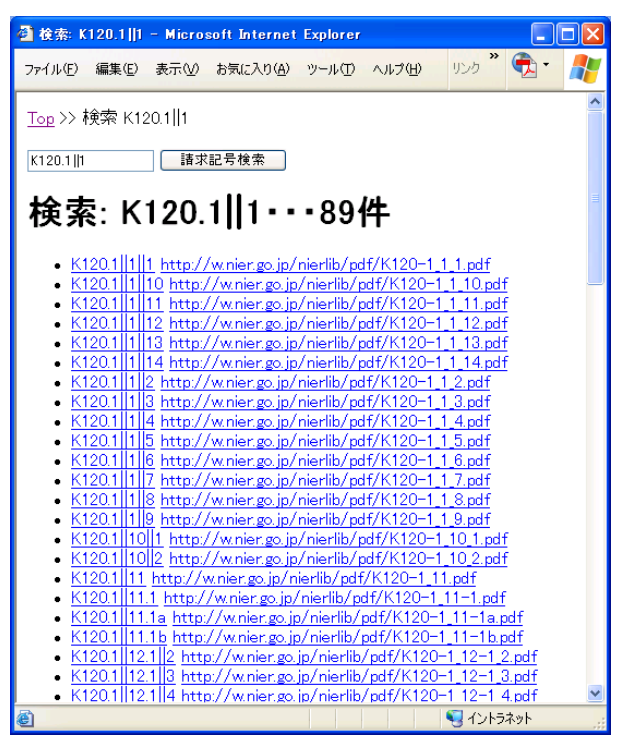

図 9 請求記号による教科書閲覧 システム : 請求記号「K120.1」の 検索結果

には，権利者に無断で当該図書館の所蔵資 料を用いて複製することができる」[25] 範 囲内として，教科書の PDF を作成してい る. 谷のため, 現在, 著作権があるかどう かの確認作業等は行なっていない．

戦前教科書の劣化や紛失を防ぐためには， 現物をなるべく利用者に触れさせない，複写 に現物を使わないようにする処置が必要で あるために PDF を作成しているのである . 
しかし，もし，Web 上に公開提供すると なれば, 公衆送信権について考慮する必要 があり，著作権があるかどうかの確認作業， 著作権が残っていれば, 許諾処理が必要と なる 。

\section{9 .2 書誌データのブラッシュアップ}

すでに述べたように，書誌データとして は, カード目録より電子化した CSV デー タがある.この書誌データと , PDF とのリ ンクを試してみたところ, 書誌データに記 載されている請求記号と教科書の現物に貼 られている請求記号シールの請求記号が異 る場合が多数ある問題が判明した．また， PDF ファイル名命名規則に反したPDF 名 が多数みつかるという事実も判明した .

カード目録だけで運用していた場合は， たとえ, カード目録の請求記号と教科書の 現物の請求記号が異なったとしても，図書 の請求を受けた図書館員の知識と経験でな んとかみつけだし, 運用することが可能で ある.しかし，これを一般の図書館利用者 に求めることは困難であるため，これらの 情報を修正する必要がある．

\section{4 今後の展望}

戦前教科書の電子化についてはまだまだ 未解決のことが多く，処理しなければなら ない問題は多いが，ここでは，教科書の電 子化が今後どのように進んでいくとよいか についての展望について述べる. 戦前教科 書の電子化と炎の応用については，4 段階 あると筆者は考える。

第一段階は, 教科書の本文画像の電子化 と，一般書籍において普通に電子化されて いる書名, 著者名, 出版年等の基本的な書 誌データの電子化が完了し, 本文画像と書 誌データがリンクされ, 書誌データから検 索・閲覧が可能になることである . 一次資 料電子化の例に挙げた広島大学図書館の教 科書コレクションにおいて，一部のみ画像 公開である教科書がなくなり, 全ての教科 書が全部画像公開されたものになれば，こ の第一段階はクリアできる .

第二段階は，教科書特有の書誌情報や内
容が電子化されて，第一段階で実現された 機能・データとリンクすることである . 教 科書特有の書誌情報には，科目，時代区分， 検定年，使用年などの教科書光のものに関 する書誌情報がある . 教科書の内容に関す る情報には例えば，唱歌の歌い出しや曲名， 国語教科書に収録されている作品の作品名 や著者名や内容などがある．

第三段階は, 教科書の本文テキストの電 子化と第二段階までの機能・データとのリ ンク，本文テキストの全文検索である .

第四段階は, 教科書以外の情報とリンク することである . 例えば，検定時代の教科 書であれば，光の教科書が検定済みである かどうかがわかる「検定済教科用図書表」と リンクする.教育制度, 教科書制度, 教育 関連事件等の年表とリンクする.教育や教 科書に関連した法律, 国会での審議, 公文 書とリンクするなどである . 他の情報源の 電子化状況によれば，第三段階と第四段階 は, 逆になることもありえるだろう .

\section{5 おわりに}

本稿では, 日本の戦前教科書の電子化と 応用について教育図書館での取りくみを中 心に述べた . 戦前の教科書の状況は, 一次 資料，二次資料ともに十分に電子化されて いる状況ではなく，教育図書館のように多 くの戦前教科書を所蔵している図書館の使 命としてよりいっ光うの研鑽が必要となる とつくづく感じた．電子化というと，教科 書のイメージを炎のまま閲覧できる一次資 料の電子化が注目されがちである.しかし， 筆者の教育図書館での経験からいうと，最 低限の正確な書誌データつまり，二次資料 がなければ，乥も光も探すことが困難であ り，せっかく一次資料を電子化しても，思う ように使用できないことがよくわかり，二 次資料の電子化・整備の重要性を痛感して いるところである .

教科書は，多くの人にとって身近な書籍 であるとともに，教育政策の歴史をみる上 でも重要な資料である. 教育図書館は, 研 究者だけでなく一般の利用者にも開放して 
おり, 教科書とともに，教育関係の資料を 一力所でまとめて利用できる図書館である . 電話やメール等のレファレンスにも応じて いるので, ぜひ活用していただきたい*9.

\section{参照文献}

[1] 全国国立教育系大学附属図書館協議会教科 書標準分類法小委員会. 教科書標準分類法. 大学研究. no. 14, 1974, p.62-78.

[2] 中村紀久二. 教科書の社会史. 東京, 岩波書 店, 2001, 244p. (4-00-430233-1).

[3] 中村紀久二編. ”凡例 3 分類”. 教科書関係文 献目録 (1970 年 1992 年). 東京, 学校教育 研究所, 1993, p.5.(4-7625-0509-9).

[4] 中村紀久二 (研究代表者). 教科書の編纂・ 発 行等教科書制度の变遷に関する調査研究: 平成 7 年度平成 8 年度科学研究費補助金 (基盤研究 B(1)) 研究成果報告書. 東京, 1997 年, 390p.

[5] 中村紀久二. 検定済教科用図書表 解題. 東 京, 芳文閣, 1986, 72p.

[6] 上原いづみ. 明治期歴史教育における「歴 史画」の研究-検定教科書の挿絵分析を通し て-. 筑波社会科研究. no. 21, 2002, p.13-22.

[7] 谷口巌. 福沢諭吉とイソップ物語-『童蒙教 草』かたわ娘』をめぐって-. 愛知教育大学 研究報告. no. 23,1974, p1-16.

[8] 亀山佳明.『『明治の英雄像』の意味と構造」一 国定教科書にみる人物像の分析-. 京都大学 教育学部紀要. no.25 1979, p.121-133.

[9] 鳥居美和子編. 明治以降教科書総合目録 I 小 学校編. 東京, 小宮山書店, 1967, 595p. (教育 文献総合目録, 第 3 集).

[10] 中村紀久二. 教科書についての参考書. 図書 館杂隹誌. vol.65, no.9, 1971, p.32-35.

[11] [20]. ”自序”, p.3.

[12] [5]. "三、「検定済教科用図書表」にもとづ く教科書研究の必要性”.p.25.

[13] 東京書籍株式会社社史編集委員会編. ”第六 章 検定制度下の東京書籍”. 近代教科書の変 遷 東京書籍 70 年史. 東京, 東京書籍, 1980, p.876.

[14] 国立国会図書館整理部編. 国立国会図書館 所蔵明治期刊行図書目録. 東京, 国立国会図 書館, 1971-1976, 6 冊.

[15] 福岡県立図書館参考調査係. 教 科書 の探し方. 2005-05, http: //www.lib.pref.fukuoka.jp/

*9 教育図書館は, 2008 年 1 月に国立教育政策研究 所の霞ヶ関への移転に伴ない, 2008 年 10 月か ら 2 月末まで休館中である。 reference/019_kyokasyo.htm 照 2007-10-29).

[16] 海後宗臣等編. 日本教科書大系近代編. 東京. 講談社. 1961 1967. 27 巻.

[17] 国立情報学研究所 開発・事業部コン テンツ課. "教科書に関する取扱い及び 解説”. NACSIS-CAT/ILL : 目録所在情 報サービスホームページ. 2005-03-25. http://www.nii.ac.jp/CAT-ILL/ manuals/text_kijun.pdf(参 照 2007-10-30).

[18] 国立情報学研究所開発・事業部コンテ ンツ課. ”コーディングマニュアル (教科 書に関する抜粋集 ) ”. NACSIS-CAT/ILL : 目録所在情報サービスホームページ. 2005-03-25. http://www.nii.ac.jp/ CAT-ILL/manuals/text_cm.pdf(参 照 2007-10-30).

[19] 広島大学図書. 広島大学図書館所蔵 教科 書コレクション. http://cross.lib. hiroshima-u.ac.jp/index.htm, (参照 2007-10-25).

[20] 鳥居美和子編. 明治以降教科書総合目録 II 中学校編. 東京, 小宮山書店, 1985, 484p. (教 育文献総合目録, 第 3 集)。

[21] 東京書籍株式会社附設教科書図書館東書文 庫編. 教科用図書目録: 東書文庫所蔵. 東京, 東京書籍, 1979 年-,3 冊.

[22] 国立教育政策研究所. 国立教育政策研究所 教育研究情報センター教育図書館. http: //www.nier.go.jp/library/, (参照 2007-10-25).

[23] 国立教育研究所編. "第 5 節 付属教育図書館 の事業 II 蔵書構成、分類、目録二分類”. 国 立教育研究所十年の歩み. 東京, 国立教育研 究所, 1961, p.196.

[24] 江草 由佳. 教育図書館における複数コレク ションの提供. ディジタル図書館. No.32, 2007, p.23-33.

[25]社団法人著作権情報センター。” ケーススタディ著作権 第 3 集”. http://www.cric.or.jp/qa/ cs03/cs03_7_qa.html (参照 2007-11$01)$. 